Article

\title{
Text You Pictures: The Role of Group Belonging, Race Identity, Race, and Gender in Older Adolescents' Mobile Phone Use
}

\author{
Valerie Barker \\ School of Journalism and Media Studies, San Diego State University, San Diego, CA 92182-4561, USA; \\ valeriebarker@valeriebarker.net
}

Received: 8 June 2018; Accepted: 2 July 2018; Published: 16 July 2018

\begin{abstract}
Prior research underscores the value of social identity in adolescent development. Guided by social identity theory and employing an online survey, this study examined mobile phone use among older adolescents (18-19 years; $n=362)$, with special emphasis on social identity: group belonging, race identity, and group markers: race and gender. The findings confirmed that social identity markers play a role in popular forms of social mobile use (e.g., texting, phone camera, and music), especially among females. Nonwhite participants were more likely to report using generic phone apps for social compensation, although whites reported higher incidence of use than nonwhites for generic phone apps, texting, and taking pictures.
\end{abstract}

Keywords: mobile phone use; older adolescents; social identity; gender; race

\section{Introduction}

Adolescents and emerging adults are often referred to as "digital natives" because they are part of an age cohort that has grown up with the internet (Hargittai 2010; Nakamura and Chow-White 2012). According to Global Web Index (Global Web Index GWI), mobile phones are the primary device for accessing social media platforms throughout the day, and also that the 16-24 age cohort is four times more likely to choose the mobile phone as their most important device when compared to 55-64 s. As a channel to digital and social media, the mobile phone is an extension of self for many young people (e.g., Han et al. 2017; Ling and Pedersen 2006). Research indicates that, on average, young people use digital and social mobile media to connect with friends, acquaintances, and to communities outside of their immediate experience (Jenkins et al. 2015). As well, digital and social media provide the ability to see, learn about—and interact with—diversity, in terms of both people and ideas (Jenkins et al. 2015). Personal self- expression and customized sociality (a mix of the diverse and familiar) are at the heart of mobile social media use. These concepts reflect personal autonomy and social connection, and thus, are at the intersection of personal and social identity development. Concerns about changes wrought in in everyday life because of such mobile phone use are often aired among parents (Anderson 2016). This is partly because adolescents and emerging adults are "reconfiguring the contract about what we thought was appropriate visibility and public behavior for young people" (Ito 2015, p. 40). Thus, academic studies, news media commentary, not-for-profit entities, and marketing endeavors, focus heavily on aspects and levels of use among this age demographic. The present study adds to this body of knowledge by investigating mobile phone use among older adolescents with special emphasis on social identity: group belonging, race identity, and group markers: gender and race. The topic of mobile phone use is approached from two perspectives. First, a summary of what is known about usage statistics across age, gender, and race is provided. This indicates that, while young people across the board are ardent users of mobile phone apps, there are demographic differences. The focus for 
race (as a demographic) in this early section is that racial minorities are more likely to use their phone for all their digital and social needs. This is essentially because of a technology gap that is associated with economic status. For gender, the differences relate to varying preferences for phone affordances (for example, adolescent girls like social media more than boys. Adolescent boys like gaming more than girls). Second, following from a general discussion of social identity among this young cohort, the connection is made between mobile phone use (and allied affordances) and identity. The relational aspect (for adolescent girls vs. boys) and the cultural community aspect (for minorities) are highlighted to establish the importance of identity (personal/social) and its connection to social mobile use.

\section{Literature Review}

\subsection{Mobile Phone Use}

Clearly, mobile phone use is about connection in its broadest sense. The mobile phone offers numerous and varied opportunities to communicate in terms of depth, breadth, and intensity. Existing data points document some of this. Investigating smartphone use in the overall United States (U.S.) population, (Aaron and Page 2015) found that smartphone ownership is especially high among younger Americans (18-29-85\%). Also, among younger adults, 15\% are heavily dependent on a smartphone for online access. Younger smartphone owners are especially avid users of text messaging (100\% 18-29-year-olds in this 2015 sample). Texting is a particularly important mode of communication for many teens. Ninety percent of teens with phones exchange texts. Social networking, video consumption, and music/podcasts are also popular with younger smartphone owners. Lenhart and Page (2015) focused specifically on teenagers' use of social media and technology, and reported that $24 \%$ of teens go online "almost constantly" and $92 \%$ are online daily via their smartphones. Facebook remains the most popular social media site among American teens ages 13 to 17 with $71 \%$ of all teens using the site while half of teens use Instagram and four-in-ten use Snapchat. Image sharing platforms are important to teens and young people because taking pictures is a way to celebrate friends (Senft and Baym 2015). Fully 83\% of American teen social media users say social media make them feel more connected to information about their friends' lives; and, $68 \%$ of teen social media users receive emotional support from people on social media platforms (see also Shensa et al. 2016).

\subsubsection{Gender Differences in Mobile Phone Use}

(Lenhart et al. 2015) report that girls dominate social media, whereas boys are more likely to play video games. Also, girls are more likely to use text messaging as conduits for conversations with friends: $62 \%$ of girls spend time with friends every day via text messaging, compared with $48 \%$ of boys. For their part, boys are more likely than girls to play video games. Girls who have met new friends online are more likely to meet them via social media, while boys are substantially more likely to meet new friends while playing games online.

\subsubsection{Racial and Ethnic Differences in Digital and Mobile Phone Use}

According to the (Pew Research Center 2018), reliance on smartphones for online access is especially common among African Americans, Hispanics, and lower income Americans. About 22\% of Hispanics and 15\% of African Americans are smartphone only internet users. This is because often they cannot afford home broadband and/or other devices to connect on the internet. This means that a large minority of nonwhites must do everything on their mobile phones.

As well, a common theme that runs through findings from Pew Research (Anderson 2015), Nielsen $(2015,2016)$ and others is that social and digital media are frequently used by minorities to celebrate and reinforce cultural and social identity. For example, a study commissioned for Facebook (People Insights 2014) found that the mobile phone is the main connector to family, friends, and information for Hispanics. Also, digital platforms are typically used as a place to nurture and sustain connections, as well as to celebrate and express an array of life experiences. 
Another study commissioned by Facebook (People Insights 2015a) discovered that community is celebrated via Facebook among African Americans. Community encompasses family in that family is defined more broadly than immediate family and it includes church community and close friends. African Americans also reported celebrating personal achievement and cultural identity via Facebook. Forty percent of 18-29-year-old African Americans who use the internet say that they use Twitter, as another place to signify race and ethnicity. Asians are more likely to own a smartphone than other racial groups, often accessing digital media via their phone. (People Insights 2015b) found that Asian Americans reported connecting in their heritage language on social media, with $42 \%$ communicating with friends in an Asian language half of the time or more. Also, $44 \%$ of Asian Americans say that accessing cultural content unavailable via other media is an important reason for using social media.

In sum: Existing research suggests that social connection is an important focus for most young mobile phone users. Social connection reflects the group in the individual and it adds affirmation, status, support, and entertainment into the mix. Personal and social identity development is the primary goal for adolescents and emerging adults. Access via mobile phones to social media platforms and a whole array of phone apps has a part to play in identity development (Manago 2015; Reich et al. 2012).

\subsection{Social Identity and Youth}

Social identity theory (SIT, Tajfel and Turner 1986) posits that social identity stems from "that part of the individual's self-concept which derives from their knowledge of their membership of a social group (or groups) together with the value and emotional significance of that membership" (Tajfel 1978, p. 63). People construct group norms during their interactions with valued in-group members and they internalize and enact such norms as part of their social identity (Turner 1982). SIT assumes that people belong to a variety of social groups that often intersect. Also, different group memberships/identities will be salient at different points in time.

In early studies, computer mediated communication scholars investigated the influences of social identity and group belonging on small group behaviors in virtual settings (see for example, Lee 2007; Tanis and Postmes 2005). In the case of social media, however, personal and social identity cues are evident. On a basic level, personal identity can be described as "... self defined and evaluated in terms of idiosyncratic personal attributes and close personal relationships with specific other people" (Hogg et al. 2017, p. 2). Social mobile users may post material that relates to their idiosyncratic tastes, but also include forms of content that act as group markers.

Adolescents and peer group belonging: Social identity and group belonging are important facets of all age groups (Tajfel and Turner 1986; Thurlow 2005); however, group belonging is particularly significant among adolescents and young people (Williams and Thurlow 2005). The World Health Organization (World Health Organization WHO) describes adolescence as spanning ages 10-19, falling within WHO's definition of young people-individuals between ages 10 and 24 . There are differences in developmental tasks at the stages of adolescence, so that in early adolescence, these are more concerned with physiological change, whereas late adolescence is associated with individualization from family (Fleming and Anderson 1986). For freshmen college students, there is an additional challenge in maintaining existing peer group belonging (Friendsickness, Paul and Brier 2001; Manago 2015), as well as transitioning to new friendship groups (Paul and Brier 2001; Rademacher and Nelson 2008).

Usually, individuals strive for a positive self-concept and seek to avoid a negative one (Tajfel and Turner 1986). From a social identity perspective, mobile media provide adolescents and emerging adults opportunities to identify with ingroup members who look, feel, and act like they do as well as to compare themselves to outgroup members. Harwood $(1997,1999 a, 1999 b)$ showed that individuals seek to use media to strengthen their identification with a social group and/or make that identification more positive.

Therefore, adolescence is a stage when peers become very important, and, as mentioned above, peers help teens cope with developmental changes (Reich et al. 2012). Clearly, adolescents spend a lot of time communicating via digital and social media-largely achieved using their mobile phones. 
Stald (2008) states that the mobile phone acts as a medium for social networking, enhancing of group identity, and for interaction between friends, which is part of the process of identity construction. It has an important role as mediator between personal and social identity. The smartphone is the focus of convergence of technologies and content, and it is easily combined with other media through wireless and wired connections. Thus, the mobile phone serves an instrumental purpose and/or a relational one so that its use can be varied and interrelated, providing adolescents social identity gratification opportunities.

\subsection{Social Identity and Social and Digital Media Use}

Across a variety of age contexts, several motives for the use of digital and social media have been identified. Apart from motives, such as passing time, entertainment, and information seeking, interpersonal and social goals have been consistently identified. For example, Valkenburg et al. (2005) found that adolescents who visited chat rooms and used instant messaging indicated that they did so to find out how others react to them, to overcome shyness, and to facilitate relationship formation. Similarly, Valkenburg and Peter (2007a) found that, via the mediator closeness to friends, digital communication was positively related to reports of wellbeing among adolescents. In an early study of college students (52\% first year), Papacharissi and Rubin (2000) investigated the influence of perceptions of social presence in relation to internet use as well as social and psychological antecedents to, and perceptions about, internet use. Those who considered the internet a warm, social, and active environment used it mainly to pass time, for convenience, interpersonal utility, and entertainment. Those who felt less secure in face-to-face interaction were more likely to turn to the internet for interactional purposes. In a more recent study of problematic Facebook use among Italian adolescents (Marino et al. 2016), found that gender, group norms, and social identity predicted the perceived frequency of Facebook use.

In relation to the current study, Walsh et al. (2009) conducted focus groups with 32 participants, which were aged between 16 and 24 years, to assess psychological influences on mobile phone use. Three major themes, connectedness, belonging, and social identity were explored in relation to young people's mobile phone use. Mobile phone use was a normative behavior among friendship networks. The authors found that easy contact with others when using a mobile phone facilitated connectedness. Also, mobile phones enhanced the feelings of belonging and social identity processes. The authors concluded that because young people are developing a sense of identity outside the immediate family environment, they rely on friends and peers to provide a sense of community and connection. As such, belongingness needs in young people may be more likely to result in a strong social identification with friendship groups, facilitated by mobile phone use.

\subsubsection{Social Identity Gratifications (SIG)}

Blumler (1985) suggested that media scholars should attend to the degree to which group members "maintain and strengthen their social identities through what they see, read and hear in the media" (p. 50). Harwood theorized that the act of choosing to interact with media content and media delivery systems serves to reinforce group belonging. Harwood (1997, 1999a, 1999b) found that television viewers across three age groups children, younger adults, and older adults showed a preference for viewing television characters of their own age. Also, individuals who showed a strong preference for shows featuring people of their own age showed a strong identification with their age group. Adolescents can now choose both legacy and new media channels to facilitate intragroup and intergroup relationships (McKay et al. 2005), as well related attitudes and behaviors. For example, drawing on SIT, and uses and gratifications theory, (Chan 2014) explored the role of individuals' group identification, SIG and Facebook group use intensity on their willingness to participate in collective actions that were instigated through a Facebook group. Factor analyses showed that motivations based on psychological affiliation with the group explained the most variance for Facebook group use. Also, SIG was the strongest mediator between group identification and the willingness to participate in collective action. 


\subsubsection{Social Compensation}

Individuals who experience loneliness or shyness could find a sense of affirmation via social media. Papacharissi (2002) discovered that personal web pages provide alternatives for authors who do not consider other communication channels rewarding. She speculated that those who find "offline life communication with friends and family less rewarding could perhaps feel more confident when communicating through their personal home page" (p. 350). Individuals who experience low or negative self-esteem-perceiving themselves or their social group to be an undesirable/unpopular one-may wish to distance themselves from others. In such situations, these persons may try to develop more comforting interpersonal and group relationships online-social compensation. For example, Peter et al. (2005) found that introverted adolescents were motivated to communicate online to compensate for lacking social skills, which increased their chances of making friends online.

\subsection{Race, Social Identity, Digital and Social Media Use}

Racial identity is often a frame in which individuals categorize others based on skin color (O'Hearn 1998). Skin color is one label that allows for individuals and groups to ally with or to distance themselves from those that they consider similar to or different from themselves (Chavez and DiBrito 1999). In the present study, race identity is treated as a social construction that is associated with sense of group belonging; that is: the perception that individuals share a common origin with ingroup members (Helms 1993). Race identity is constructed in concert with ingroup others and in comparison to outgroups. This point of connection helps group members to interpret the world and to feel pride in who they are. People vary in the strength by which they identify with people of their own skin color, cultural values, behaviors, beliefs, and traditions. Thus, participants in the current study were asked to indicate this level of racial identification without direct reference to their racial background.

Extant research does highlight the differences between racial groups regarding digital and social media use. For example, academic research about African Americans and digital space has focused upon the prevalence of types of mobile phone use and identity motivations for use, as well as attempts to understand specific instances of these, such as "Black Twitter". Overall, these studies underscore a strong motivation to enact, celebrate and share "being Black" both with those who are close and those who represent weak ties who are also Black (e.g., Florini 2014). As well, Lee $(2012,2015)$ conducted research examining Facebook usage among African American college students. The findings emphasized the importance of identity presentation and communication with other African American students on Facebook. Social interaction anxiety was another important indicator of heavy use of smartphones and Facebook, reflecting social compensation findings in other studies.

There is a lack of empirical research examining Hispanic mobile phone use and identity among adolescents and emerging adults. The Facebook (People Insights 2014) mentioned earlier does show that Hispanic people in the United States regard social media as very important tools to maintain connections with family members and to provide a way of celebrating culture and language. Regarding teens, Reich et al. (2012) conducted a study, employing an in-person survey $(n=250)$ and a follow up online survey $(n=126)$ with mostly Latino high school students (70\%; 13-19 years-old). As in other studies, the findings showed that these adolescents use social media to connect with offline friends to strengthen existing relationships. Racial group identity and race as a group marker may influence how and why young people use social mobile apps, especially as racial minorities rely more heavily on mobile phones than do whites. The present study seeks to assess the associations between forms of mobile phone use and perceptions about social identity (group belonging, race identity), SIG, and social compensation

Therefore, based on research discussed so far, the following hypotheses are advanced: 
Hypothesis 1 (H1). There will be a positive relationship between assessments of social identity (group belonging, race identity) and forms of social mobile use associated with facilitation of ingroup connection such as texting, phone camera and music.

As discussed, social compensation seeking is an outcome associated with a lack of belonging or an affinity with group members with whom one interacts offline. Thus, it is expected that those seeking social compensation via their phone apps would be unlikely to express a sense of ingroup belonging with others. Therefore, the second hypothesis posits that:

Hypothesis 2 (H2). There will be a negative relationship between group belonging and phone use for social compensation.

Similarly, it is unlikely that individuals seeking social compensation would feel a sense of ingroup gratification via phone apps since they do not feel associated with the offline group members who interact in social media spaces. And so, the third hypothesis predicts that:

Hypothesis 3 (H3). There will be a negative relationship between phone use for social compensation and social identity gratifications from phone use.

Research reveals a considerable equivalence in identity motivations for the use of digital and social mobile devices among young people; however, there is evidence for gender differences in type of use, affordances, and forms of identification.

\subsection{Social Identity, Gender Differences and Mobile Phone Use}

Research suggests that, although teenage girls and boys make frequent use of digital and social media, the way that they use media is different (see Anderson 2015; Gross et al. 2002; Joiner et al. 2005). Boys focus on features and entertainment-value (especially video games); girls seem more interested in the relational aspects of digital media (particularly social networking platforms). In early research, (Raine 2003) reported that girls are more likely to talk online about romantic relationships, secret things, and deep feelings than are boys (see also, Valkenburg and Peter 2007b). Boys are more likely to talk about sex, movies, TV shows, sports, and video games. Females, more than males, use text messaging to facilitate relationship depth (intimacy) and to kill time, whereas males use text messaging for relationship breadth (meeting others) more so than females (Morrill et al. 2013). Females also tend to use more positive emoticons in texts than do males (Ceccucci et al. 2013). Adolescent girls are more likely to use their cell phone intensively when compared to adolescent boys (Sánchez-Martínez and Otero 2009). Such gender differences in the form and topics of communication are reflected in the content of teenagers' blogs (Huffaker and Calvert 2005) and the formatting of web pages, including text, color, and graphics (Döring 2002).

In a survey involving freshmen (17-19 years), Barker (2009) investigated the potential influence of group belonging and gender on social media use. Females, as compared to males, were more interested in communication with peer group members and reported more habitual social media use for entertainment and passing time. Students who reported negative collective self-esteem expressed greater interest in social compensation via social media as an alternative to communicating with offline peers. In a follow up study, Barker and Ota (2011) conducted a survey of white American and Japanese young women (age range 18-19), which investigated cultural differences in types of social networking site use and motives for use. Although there were some disparities between American and Japanese females in motives for social networking site use, generally the main motive was the communication with ingroup peers known offline. Participants reported lesser use for social identity gratifications and social compensation. American young women were more prone to public expressions of connection with peer group using photographs. Japanese young women were much more likely to communicate closeness via diaries. 
Much of the research discussed above relates to social media specifically and not to mobile phone use on a more general level. Also, research findings addressing the relationships between forms of social identity or social identity markers and mobile phone use have been somewhat varied in nature. Therefore, in the present study, the following research questions are posed:

RQ1: Do gender and/or race/ethnicity play a role in the relationships between group belonging, SIG, and social compensation and forms of mobile phone use?

RQ2: What are the most telling social psychological and demographic predictors of popular forms of phone use?

\section{Method}

Participants $(n=362)$ were recruited via Sona Systems, which provides subject pool software for universities. Students earned extra credit points for their participation in spring, 2017. The sample was predominantly white $(n=242)$. The remaining participants were Hispanic $=84$; African American $=20$; Asian American $=76$. Some participants self-reported more than one ethnicity. Most of the participants were female $(n=224$; male $=138)$. Participants were required to be either 18 - $(n=128)$ or 19 years-old $(n=234)$.

\subsection{Measures}

In addition to items asking for demographic information (e.g., age, gender, race/ethnicity), there were several scales measuring variables of interest. These included frequency and types of mobile phone use (Anderson 2015; Auter 2007). Two forms of social identity were assessed: group belonging (Hogg and Hains 1996) and a diagrammatic race identification measure (Tropp and Wright 2001), social compensation (adapted from Barker 2009), and social identity gratifications (adapted from Harwood 1997). The participants' scores were the overall means of the items comprising the scales. All of the items were closed-ended and participants typically responded on a five-point range (e.g., $1=$ very strongly disagree; $5=$ very strongly agree). Statistical significance was assessed using a 95\% decision rule $(p<0.05)$. The measures, Cronbach alphas, and descriptives are shown in Table 1.

Table 1. Measures.

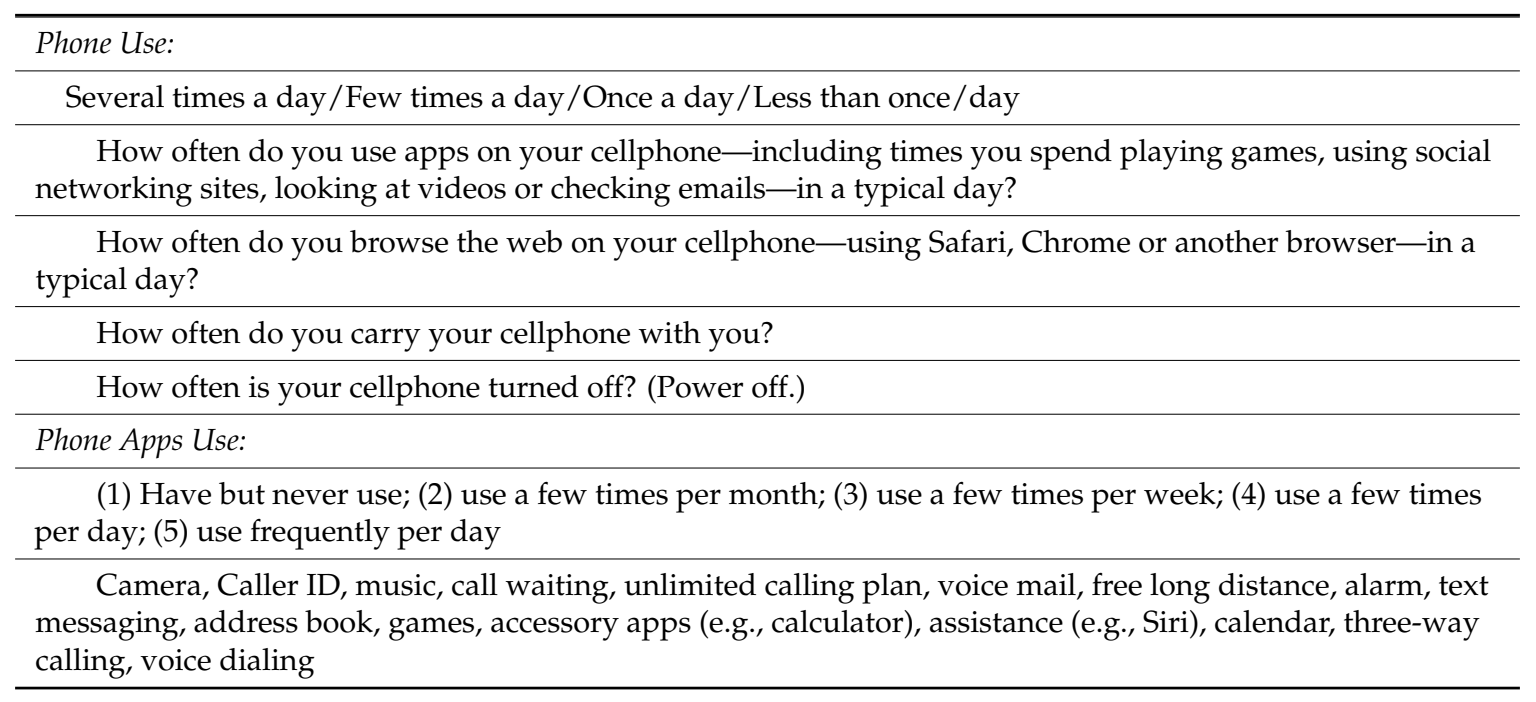


Table 1. Cont.

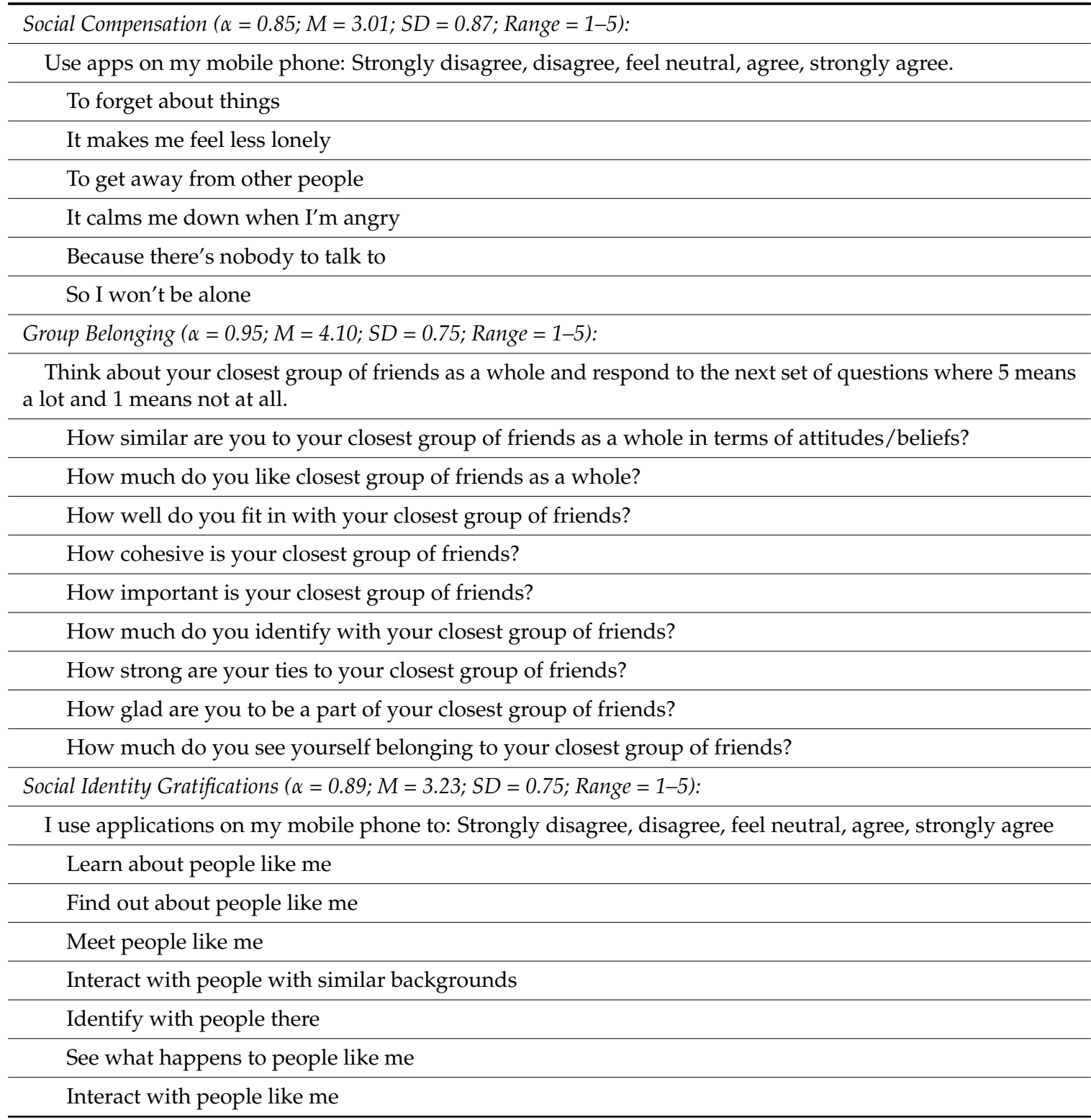

\subsection{Data Analysis}

The scale items were coded positively; therefore, a high score indicated higher group identification, social compensation, etc. Initial hypothesis testing involved the computation of zero order Pearson Product Moment Correlations. ANOVA tests were used to assess both main effects and interaction effects. For significant interactions, simple slopes analysis was conducted (Preacher et al. 2006). To determine the predictors of the generic use of phone apps and the most popular forms of phone use, linear regression analysis was performed.

\section{Results}

In terms of frequency of use, $90 \%$ of participants reported that they use their mobile phone to access apps several times per day. Fifty-five percent use their phone to browse the web several times per day. Eighty-Eight percent of participants always carry their phone and 55\% said that their phone is rarely turned off. Regarding the most popular mobile phone features that were used frequently every day: $81 \%$ reported texting $(M=4.73 ; S D=0.79) ; 47 \%$ use their phone for music $(M=3.90 ; S D=1.37)$, 
$42 \%$ use their phone camera $(\mathrm{M}=4.00 ; \mathrm{SD}=1.05), 30 \%$ reported using the phone accessories $(\mathrm{M}=3.71$; $\mathrm{SD}=1.08)$, and $17 \%$ said that they play games on their phone $(\mathrm{M}=2.83 ; \mathrm{SD}=1.43)$.

Hypothesis testing: The bivariate relationships for the hypotheses are shown in Table 2.

Hypothesis 1 (H1). Group belonging was positively related to mobile phone use for generic phone apps, texting, camera and music. Notably, group belonging was positively associated with race identity $(r=0.14 ; p<0.01)$ Race identity was positively related to phone use for web browsing, texting, camera, music and phone accessories. Therefore, this hypothesis was confirmed.

Hypothesis 2 (H2). As predicted, group belonging was negatively associated with phone use for social compensation.

Hypothesis 3 (H3). This hypothesis predicted a negative relationship between phone use for social compensation and SIG. Contrary to expectations, there was a positive, significant relationship between social compensation and SIG. However, a paired samples t test revealed a significant difference in the means for these two variables ( $S I G M=3.23, S D=0.75 ;$ social compensation $M=2.99, S D=0.86 ; t$ (347) $4.33 p<0.0001$ ).

All of the associations between different types of mobile phone use and the proposed independent variables are summarized in Table 2.

Table 2. Correlations: Social Psychological Attributes, Demographic Characteristics, and Mobile Phone Use.

\begin{tabular}{|c|c|c|c|c|c|c|}
\hline Measures & Group Belonging & Social Comp & SIG & Gender & Race ID & White/Nonwhite \\
\hline Group Belonging & & $-0.12 *$ & n.s. & n.s. & $0.14 * *$ & n.s. \\
\hline Social Comp & & & $0.25 * *$ & $0.17^{* *}$ & n.s. & $-0.26^{* *}$ \\
\hline SIG & & & & $0.12 *$ & n.s. & n.s. \\
\hline Gender & & & & & n.s & n.s. \\
\hline Race ID & & & & & & 0.12 * \\
\hline Use Apps & $0.20 * *$ & n.s. & n.s. & $0.11 *$ & n.s. & 0.14 * \\
\hline Browse Web & n.s. & $0.14^{* *}$ & $0.12 *$ & n.s. & $0.13 *$ & n.s. \\
\hline Texting & $0.32 * *$ & n.s. & n.s. & $0.14^{* *}$ & $0.17 * *$ & 0.13 \\
\hline Camera & $0.17^{* *}$ & n.s. & n.s. & $0.21^{* *}$ & 0.14 * & 0.13 \\
\hline Music & $0.17 * *$ & n.s. & $0.13 *$ & n.s. & $0.11 *$ & $-0.14 *$ \\
\hline Games & n.s. & n.s. & n.s. & -0.14 * & n.s. & n.s. \\
\hline Accessories & n.s. & n.s. & n.s. & n.s. & 0.13 * & n.s. \\
\hline
\end{tabular}

${ }^{*} p<0.05,{ }^{* *} p<0.01$; Gender: Male $=0 ;$ Female $=1$.

RQ1: Gender. Gender (female) was associated with generic phone app use, as well as texting and camera use. Also, there was a significant relationship between gender (male) and phone gaming. It was noted that gender (female) was associated with social compensation $(\mathrm{r}=0.17 ; p<0.001)$ and SIG $(\mathrm{r}=0.12 ; p<0.05)$.

Race: The subsamples for racial minorities were too small for meaningful comparisons. However, in a supplementary response to RQ1, comparisons were made based on white $(n=240)$ and nonwhite $(n=120)$ participants. ANOVA tests revealed that there were significant differences for whites/nonwhites on race identity (white $\mathrm{M}=4.55, \mathrm{SD}=1.69$; nonwhite $\mathrm{M}=4.12, \mathrm{SD}=1.76 ; \mathrm{F}(1 / 324)$ $=4.44, p<0.05$ ) and social compensation (white $\mathrm{M}=2.87, \mathrm{SD}=.87$; nonwhite $\mathrm{M}=3.33, \mathrm{SD}=0.81$; $\mathrm{F}(1 / 324)=21.09, p<0.0001)$. Also, among nonwhite participants, there was a bivariate relationship between use of generic phone apps and social compensation $(\mathrm{r}=0.23 ; p<0.05)$. Thus, a further ANOVA test was employed to test for an interaction between white/nonwhite and social compensation for generic phone apps, This confirmed the main effects for white/nonwhite $(\mathrm{F}(1 / 350)=9.59, p<0.01)$, social compensation $(\mathrm{F}(1 / 350)=10.21, p<0.01)$, and the interaction effect white/nonwhite*social compensation on generic phone app use $(\mathrm{F}(1 / 350)=6.04, p<0.05)$. Simple slopes analysis revealed that, for whites, there was no relationship between the use of generic phone apps and social compensation, but for nonwhites there was a significant positive relationship. See Figure 1. 

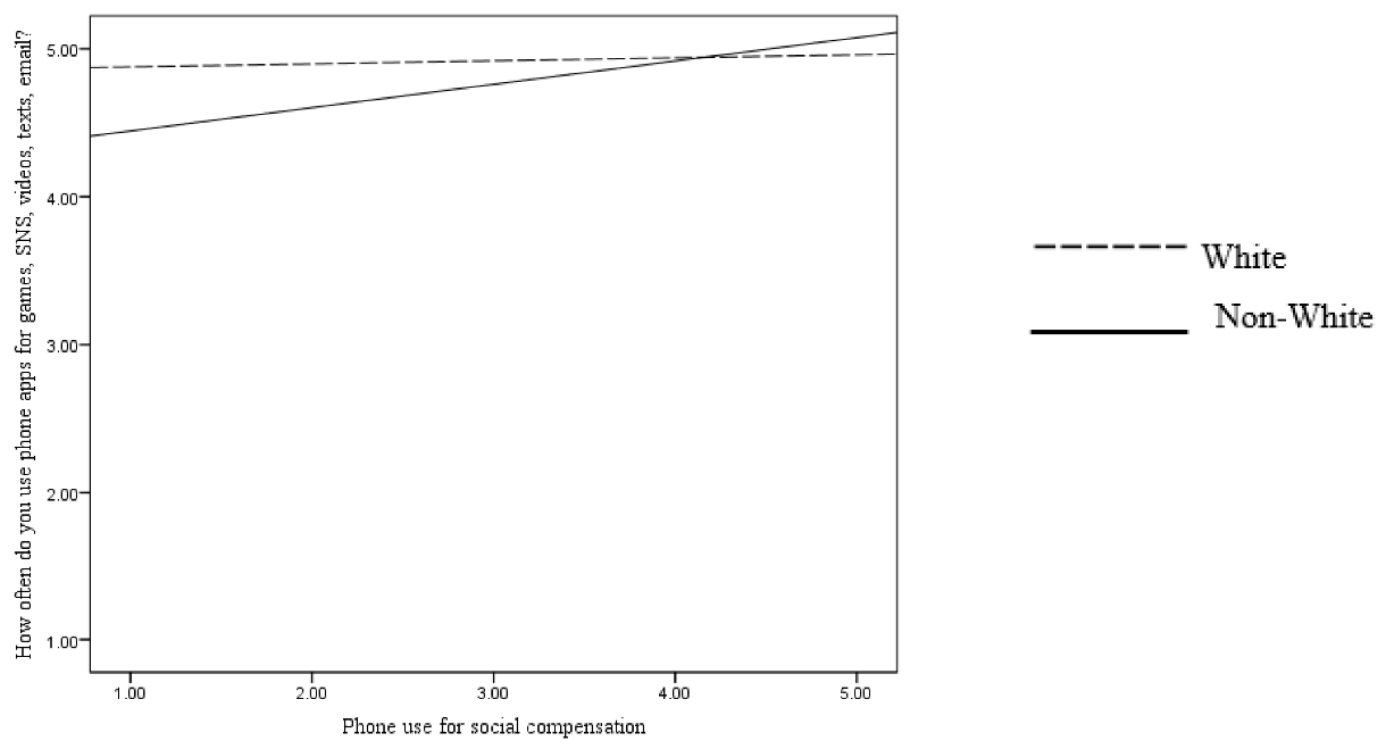

At $x=0=c v 1$. Nonwhite

simple intercept $=4.7619(0.0399), \mathrm{t}=119.1956, \mathrm{p}=0$

simple slope $\quad=0.1577(0.0469), \mathrm{t}=3.3647, \mathrm{p}=0.0009$

At $x=1=\mathrm{cv} 2$. White

simple intercept $=4.9188(0.0265), \mathrm{t}=185.7803, \mathrm{p}=0$

simple slope $\quad=0.0206(0.0303), \mathrm{t}=0.6789, \mathrm{p}=0.4977$
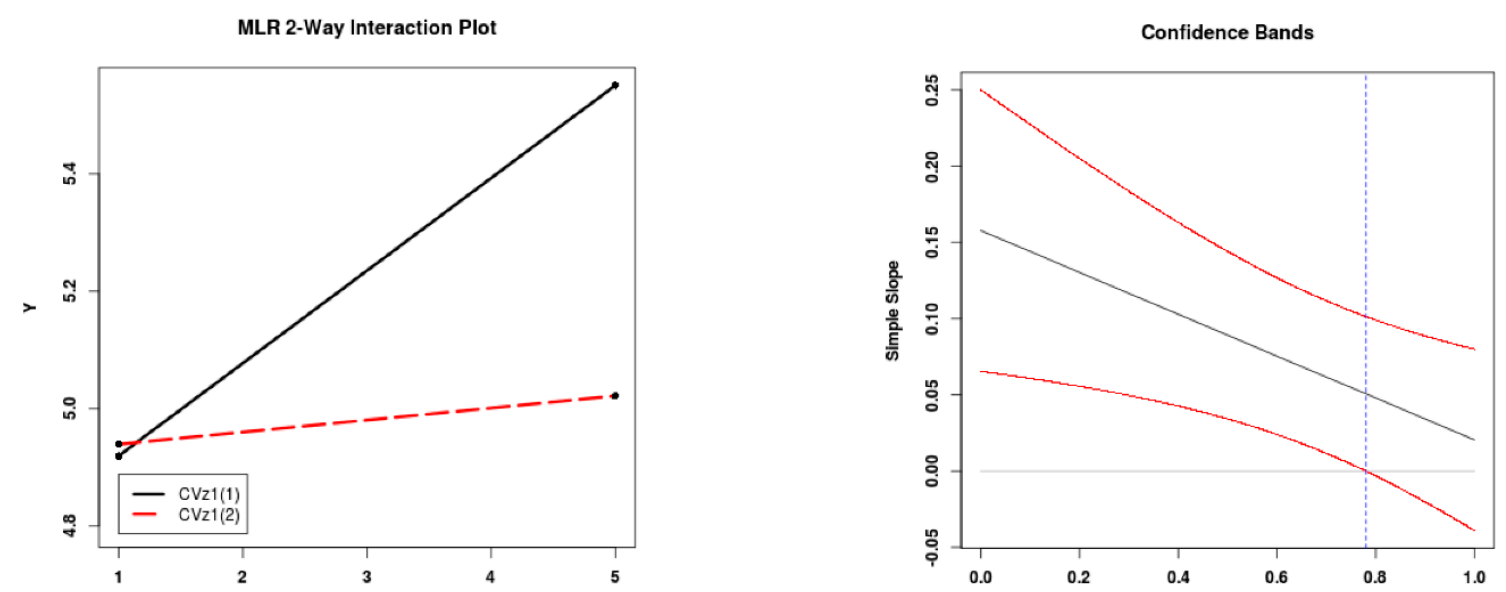

Figure 1. White/Nonwhite Interaction for Phone Apps Use by Social Compensation.

RQ2: Predicting phone apps use. Based on the forgoing analyses, and to assess the relative influence of the variables that are associated with the most popular forms of phone use in the current sample, four hierarchical regression analyses were performed to predict the generic use of phone apps, texting, phone camera use, and music. The results of these analyses are displayed in Table 3. 
Table 3. Regression Analyses: Predictors of Generic Phone App Use, Texting, and Phone Camera.

\begin{tabular}{|c|c|c|c|c|c|}
\hline Dependent Variable (Mean/SD) & Independent Variable & DF & $\mathbf{F}$ & Beta & $R^{2}$ \\
\hline \multirow{4}{*}{$\begin{array}{c}\text { Generic Phone Apps } \\
(4.89 / 0.40)\end{array}$} & Group Belonging & \multirow{4}{*}{$4 / 324$} & \multirow{4}{*}{5.18} & $0.19 * *$ & \multirow{4}{*}{0.06} \\
\hline & Race Identity & & & 0.03 & \\
\hline & White & & & 0.09 & \\
\hline & Gender & & & 0.10 & \\
\hline \multirow{4}{*}{$\begin{array}{c}\text { Texting } \\
(4.73 / 0.73)\end{array}$} & Group Belonging & \multirow{4}{*}{$4 / 320$} & \multirow{4}{*}{12.18} & $0.30^{* *}$ & \multirow{4}{*}{0.12} \\
\hline & Race Identity & & & $0.12 *$ & \\
\hline & White & & & 0.04 & \\
\hline & Gender & & & $0.11 *$ & \\
\hline \multirow{4}{*}{$\begin{array}{c}\text { Phone Camera } \\
(4.00 / 1.05)\end{array}$} & Group Belonging & \multirow{4}{*}{$4 / 320$} & \multirow{4}{*}{9.71} & $0.19 * *$ & \multirow{4}{*}{0.11} \\
\hline & Race Identity & & & 0.07 & \\
\hline & White & & & $0.14^{* *}$ & \\
\hline & Gender & & & $0.20 * *$ & \\
\hline \multirow{4}{*}{$\begin{array}{c}\text { Music } \\
(3.90 / 1.38)\end{array}$} & Group Belonging & \multirow{4}{*}{$4 / 309$} & \multirow{4}{*}{6.63} & $0.17 * *$ & \multirow{4}{*}{0.07} \\
\hline & SIG & & & $0.11 *$ & \\
\hline & Race ID & & & 0.10 & \\
\hline & White & & & $-0.16^{* *}$ & \\
\hline
\end{tabular}

The results of the regression analyses indicate that, overall, group belonging was the strongest predictor of the most popular forms of mobile phone use: phone apps, texting, camera use, and music. Gender (female) was a lesser predictor of texting and camera use. Being white was a predictor of phone camera use and being nonwhite was a predictor of phone use for music. Racial identity was a weak predictor of texting and SIG was a predictor of phone use for music.

\section{Discussion}

As confirmed in the current study, the mobile phone is ubiquitous among adolescents and emerging adults. Phones are carried almost all of the time and are virtually always on. This is because it is possible to achieve so much while using a mobile phone, both instrumentally and expressively. For example, a phone can be used to download and listen to music. But, the choice of music as shared on social media expresses something about the personal and social identity of the user (Harwood 2015). Sometimes there is a tendency to associate negative outcomes with phone app use among young people with an added note of moral panic (Jenkins et al. 2015). By contrast, prior research has associated social media use with positive motivations, such as group belonging and reinforcement-important dimensions of adolescent development. This study investigated potential social psychological antecedents (group belonging, race identity, SIG, social compensation) to the frequency of use of popular types of mobile phone use. As well, the role of gender and race as factors in these relationships were assessed.

\subsection{Group Belonging, Gender, and Racial Identity}

The data confirm that group belonging is the most telling social psychological attribute that is associated with frequently used mobile phone features. This finding is in line with social identity theory, which suggests that the in group-in-self is central to young people who place a high value on communication and interaction with and support from their most valued group of friends. Relatedly, it is noteworthy that the means for generic and specific uses of phone apps, such as texting, phone camera, and music, as well as group belonging, were high in this sample. Gender was also a correlate of phone use for texting and phone camera use. To an extent, this finding reflects the results of a study about communication with friends and family conducted among United Kingdom (UK) university students (Colly et al. 2010), on personal importance of camera phone pictures. The results showed the 
greater use of images by women than among men, among all-female dyads and to communicate with female recipients.

As mentioned earlier, group belonging and racial identification were associated and race identification was also related to the use of the most commonly used phone apps-another indication of the potential potency of identity for these participants. Phone use for music was also high in this sample. Music is an ingroup marker (Harwood 2015, 2017; Tekman and Hortaçsu 2002), as indicated by its association with group belonging, racial identity, and SIG in this study.

\subsection{SIG}

Although SIG did not feature as a correlate of many of the apps available via mobile phone, it did relate to phone use for browsing the web and for music. These relationships make sense in that if an individual is interested in observing, interacting, and seeking information about likeminded or similar ingroup people then browsing using the phone would be a way to do that. Clearly, the participants use their phones frequently to search the internet $(\mathrm{M}=4.45, \mathrm{SD}=0.70$, range $1-5)$. Also, the saying that "birds of a feather flock together" is an appropriate analogy since people who are similar either personally, racially, and/or culturally are likely to share similar tastes in music and to play and seek out music of that type. The main predictors of phone use for music were group belonging, SIG, race identity, and being nonwhite.

\subsection{Social Compensation}

Here, females were more likely than males to report using their phone for social compensation, but they were also more likely to use their phone for SIG. Social compensation is about looking for personal relationships online, whereas SIG is about identifying with similar others online. Potentially, these are two sides of a coin representing phone use for relational purposes and this, perhaps, explains the positive (as opposed to the predicted negative) relationship between social compensation and SIG. To an extent, this finding reflects prior research revealing a relational motive for social media use among girls and women (Lenhart and Page 2015).

The finding that nonwhite participants were more likely to use generic phone apps for social compensation is puzzling since whites were generally more likely to use their phones than nonwhites for generic phone apps, as well as for texting and taking pictures. Possibly, for nonwhites, this represents a form of distraction via their phones, rather than a focused attempt to find an alternative to real time communication with others. Alternatively, it could be that these participants sometimes use their phones to alleviate a sense of marginalization. Interestingly, in this regard, although the means for race identity were high across all participants, the mean for whites was higher than for nonwhites. Also, the items comprising the social compensation scale do underscore a desire to "get away from things". The participants were asked how likely they were to use their phones to forget about things, to feel less lonely, get away from other people, to calm down, and avoid loneliness when they have nobody to talk to. Further research is required in order to elaborate on this outcome.

\subsection{Limitations and Further Research}

The study employed a convenience sample that cannot be considered representative, especially because of the gender imbalance. Participants were predominantly white, and so it was not feasible to make true ethnic and racial comparisons. As well, as mentioned above, future research should assess a much more varied list of motivations for phone use. For example, prior research consistently identifies passing time and/or staving off unwanted interactions (Stald 2008) as common motivations for phone use. The next steps involve a more representative sample, applying lessons that were learned from the current data. Studies with younger cohorts are necessary because of known developmental differences between adolescent stages. Additionally, research should include experimental designs to assess the relative importance of the antecedents that were investigated in the 
current study. As well, content analyses of texts, phone photographs, and types of music could add insights to the role of social identity in social mobile use.

Funding: This research received no external funding.

Conflicts of Interest: I have no conflict of interest.

\section{References}

Anderson, Monica. 2015. How Having Smartphones (or not) Shapes the Way Teens Communicate. Available online: http:/ / www.pewresearch.org/fact-tank/2015/08/20/how-having-smartphones-or-notshapes-the-way-teens-communicate/ (accessed on 12 July 2018).

Anderson, Monica. 2016. Parents, Teens and Digital Monitoring. Available online: http://www.pewinternet.org/ 2016/01/07/parents-teens-and-digital-monitoring/ (accessed on 12 July 2018).

Auter, Philip J. 2007. Portable social groups: Willingness to communicate, interpersonal communication gratifications, and cell phone use among young adults. International Journal of Mobile Communications 5: 139-55. [CrossRef]

Barker, Valerie. 2009. Older Adolescents' Motivations for Use of SNS: The Influence of Gender, Group Identity and Collective Self-esteem. Cyberpsychology E Behavior 12: 209-13.

Barker, Valerie, and Hiroshi Ota. 2011. Mixi diary vs. Facebook pictures: Collective self-esteem and social networking site use among Japanese and Caucasian American females. Journal of Intercultural Communication Research 40: 39-63. [CrossRef]

Blumler, Jay G. 1985. The Social Character of Media Gratifications. Sage Beverly Hills: Media Gratifications Research, pp. 41-60.

Ceccucci, Wendy, Alan Peslak, S. E. Kruck, and Patricia Sendall. 2013. Does Gender Play a Role in Text Messaging? Issues in Information Systems 14: 186-94.

Chan, Michael. 2014. Social identity gratifications of social network sites and their impact on collective action participation. Asian Journal of Social Psychology 3: 229-35. [CrossRef]

Chavez, Alicia Fedelina, and Florence Guido DiBrito. 1999. Racial and ethnic identity and development. New Directions for Adult and Continuing Education 84: 39-47. [CrossRef]

Colly, Ann, Zazie Todd, Adrian White, and Tamara Turner-Moore. 2010. Communication using camera phones among young men and women: Who sends what to whom? Sex Roles 63: 348-60. [CrossRef]

Döring, Nicola. 2002. Personal home pages on the Web: A review of research. Journal of Computer-Mediated Communication 3: JCMC737.

Fleming, Wm Michael, and Stephen A. Anderson. 1986. Individuation from the family of origin and personal adjustment in late adolescence. Journal of Marital and Family Therapy 12: 311-15. [CrossRef]

Florini, Sarah. 2014. Tweets, tweeps, and signifyin': Communication and cultural performance on "Black Twitter". Television E New Media 15: 223-37.

Global Web Index (GWI). 2017. Trends: Trends to Watch in 2017. Available online: https:/ /cdn2.hubspot.net/ hubfs/304927/Downloads/Trends-17.pdf (accessed on 12 July 2018).

Gross, Elisheva F., Jaana Juvonen, and Shelly L. Gable. 2002. Internet use and well-being in adolescence. Journal of Social Issues 58: 75-90. [CrossRef]

Han, Seunghee, Ki Joon Kim, and Jang Hyun Kim. 2017. Understanding nomophobia: Structural equation modeling and semantic network analysis of Smartphone separation anxiety. Cyberpsychology, Behavior, and Social Networking 20: 419-27. [CrossRef] [PubMed]

Hargittai, Eszter. 2010. Digital na(t)ives? Variation in internet skills and uses among members of the "Net Generation". Sociological Inquiry 80: 92-113. [CrossRef]

Harwood, J. 1997. Viewing age: Lifespan identity and television viewing choices. Journal of Broadcasting and Electronic Media 41: 203-13. [CrossRef]

Harwood, Jake. 1999a. Age identification, social identity gratifications, and television viewing. Journal of Broadcasting and Electronic Media 43: 123-36. [CrossRef]

Harwood, Jake. 1999b. Age identity and television viewing preferences. Communication Reports 12: 85-90. [CrossRef]

Harwood, Jake. 2015. Communication and Music in Social Interaction. San Diego: Cognella. 
Harwood, Jake. 2017. Music and intergroup relations: Exacerbating conflict and building harmony through music. Review of Communication Research 5: 1-34.

Helms, Janet E. 1993. I also Said, “White Racial Identity Influences White Researchers”. The Counseling Psychologist 70: 240-43. [CrossRef]

Hogg, Michael A., and Sarah C. Hains. 1996. Intergroup relations and group solidarity: Effects of group identification and social beliefs on depersonalized attraction. Journal of Personality and Social Psychology 70: 295. [CrossRef]

Hogg, Michael A., Dominic Abrams, and Marilynn B. Brewer. 2017. Social identity: The role of self in group processes and intergroup relations. Group Processes $\mathcal{E}$ Intergroup Relations 20: 1-12.

Huffaker, David A., and Sandra L. Calvert. 2005. Gender, identity, and language use in teenage blogs. Journal of Computer Mediated Communication 10: 1. Available online: http://jcmc.indiana.edu/vol10/issue2/huffaker. html (accessed on 12 July 2018). [CrossRef]

Ito, M. 2015. Youth culture, youth practices. In Participatory Culture in a Networked Era: A Conversation on Youth, Learning, Commerce, and Politics. Edited by Henry Jenkins, Mizuko Ito and Danah Boyd. Cambridge: Polity Press, pp. 32-59.

Jenkins, Henry, Mizuko Ito, and Danah Boyd. 2015. Participatory Culture in a Networked Era: A Conversation on Youth, Learning, Commerce, and Politics. Cambridge: Polity Press.

Joiner, Richard, Jeff Gavin, Jill Duffield, Mark Brosnan, Charles Crook, Alan Durndell, Pam Maras, Jane Miller, Adrian J. Scott, and Peter Lovatt. 2005. Gender, Internet identification, and Internet anxiety: Correlates of Internet use. Cyberpsychology \& Behavior 8: 371-78.

Lee, E. Bun. 2012. Young, Black and connected: Facebook usage among African American college students. Journal of Black Studies 43: 336-54. [CrossRef] [PubMed]

Lee, E. Bun. 2015. Too much information: Heavy smartphone and Facebook utilization by African American young adults. Journal of Black Studies 46: 44-61. [CrossRef]

Lee, Eun-Ju. 2007. Deindividuation effects on group polarization in computer mediated communication: The role of group identification, public-self-awareness, and perceived argument quality. Journal of Communication 57: 385-403. [CrossRef]

Lenhart, Amanda, and Dana Page. 2015. Teens, Social Media and Technology Overview. Available online: http:/ / www.pewinternet.org/files/2015/04/PI_TeensandTech_Update2015_0409151.pdf (accessed on 12 July 2018).

Lenhart, Amanda, Aaron Smith, Monica Anderson, Maeve Duggan, and Andrew Perrin. 2015. Teens, Technology and Friendship. Available online: http://www.pewinternet.org/files/2015/08/Teens-andFriendships-FINAL2.pdf (accessed on 12 July 2018).

Ling, Rich, and Per E. Pedersen, eds. 2006. Mobile Communications: Re-Negotiation of the Social Sphere. Berlin: Springer Science \& Business Media, vol. 31.

Manago, Adriana M. 2015. Identity development in the digital age: The case of social networking sites. In The Oxford Handbook of Identity. New York: Oxford University Press, pp. 508-24.

Marino, Claudia, Alessio Vieno, Massimiliano Pastore, Ian P. Albery, Daniel Frings, and Marcantonio M. Spada. 2016. Modeling the contribution of personality, social identity and social norms to problematic Facebook use in adolescents. Addictive Behaviors 63: 51-56. [CrossRef] [PubMed]

McKay, Susan, Crispin Thurlow, and Heather Toomey-Zimmerman. 2005. Wired whizzes or techno-slaves? Young people and their emergent communication technologies. In Talking Adolescence: Perspectives on Communication in the Teenage Years. Edited by Angie Williams and Crispin Thurlow. New York: Peter Lang, pp. 185-206.

Morrill, Torrey B., Randall M. Jones, and J. Mitch Vaterlaus. 2013. Motivations for text messaging: Gender and age differences among young adults. North American Journal of Psychology 15: 1.

Nakamura, Lisa, and Peter Chow-White. 2012. Introduction-Race and digital technology: Code the color line, and the information society. In Race after the Internet. Edited by Lisa Nakamura and Peter Chow-White. London: Routledge, pp. 1-18.

Nielsen. 2015. Multifaceted Connections: African American Media Usage Outpaces Across Platforms. Available online: http:/ / www.nielsen.com/us/en/insights/news/2015/multifaceted-connections-africanamerican-media-usage-outpaces-across-platforms.html (accessed on 12 July 2018). 
Nielsen. 2016. Nielsen Social Media Report. Available online: http:/ /www.nielsen.com/content/dam/corporate/ us/en/reports-downloads/2017-reports/2016-nielsen-social-media-report.pdf (accessed on 12 July 2018).

O’Hearn, Claudine Chiawei. 1998. Half-and-Half Writers on Growing up Biracial and Bicultural. New York: Pantheon Books.

Papacharissi, Zizi. 2002. The presentation of self in virtual life: Characteristics of personal home pages. Journalism \& Mass Communication Quarterly 79: 643-60.

Papacharissi, Zizi, and Alan M. Rubin. 2000. Predictors of Internet use. Journal of Broadcasting and Electronic Media 44: 175-96. [CrossRef]

Paul, Elizabeth L., and Sigal Brier. 2001. Friendsickness in the transition to college: Precollege predictors and college adjustment correlates. Journal of Counseling and Development 79: 77-89. [CrossRef]

People Insights. 2014. Digital Diversity: A Closer Look at US Hispanics. Available online: https:/ /www.facebook. $\mathrm{com} / \mathrm{iq} /$ articles/digital-diversity-a-closer-look-at-us-hispanics (accessed on 12 July 2018).

People Insights. 2015a. Digital Diversity: A Closer Look at African Americans in the US. Available online: https:/ / www.facebook.com/iq/articles/digital-diversity-a-closer-look-at-african-americans-in-the-us (accessed on 12 July 2018).

People Insights. 2015b. Digital Diversity: A Closer Look at Asian Americans in the US. Available online: https: / www.facebook.com/iq/articles/digital-diversity-a-closer-look-at-asian-americans-in-the-us? ref=wpinsights_rd (accessed on 12 July 2018).

Peter, Jochen, Patti M. Valkenburg, and Alexander Schouten. 2005. Developing a model of adolescent friendship formation on the Internet. CyberPsychology E Behavior 8: 423-30.

Pew Research Center. 2018. Mobile Fact Sheet. Available online: http:/ / www.pewinternet.org/fact-sheet/mobile/ (accessed on 12 July 2018).

Preacher, Kristopher J., Patrick J. Curran, and Daniel J. Bauer. 2006. Computational tools for probing interaction effects in multiple linear regression, multilevel modeling, and latent curve analysis. Journal of Educational and Behavioral Statistics 31: 437-48. [CrossRef]

Rademacher, Mark A., and Michelle R. Nelson. 2008. Make New Friends/Keep the Old: Media, Social Networks, and Identity during the College Transition. Paper presented at the Meeting of the International Communication Association, Montreal, Canada, 25 May.

Raine, Lee. 2003. Teenage Life Online. Available online: https://slideplayer.com/slide/4416436/ (accessed on 12 July 2018).

Reich, Stephanie M., Kaveri Subrahmanyam, and Guadalupe Espinoza. 2012. Friending, IMing, and hanging out face-to-face: Overlap in adolescents' online and offline social networks. Developmental Psychology 48: 356-68. [CrossRef] [PubMed]

Sánchez-Martínez, Mercedes, and Angel Otero. 2009. Factors associated with cell phone use in adolescents in the community of Madrid (Spain). CyberPsychology E Behavior 12: 131-37.

Senft, Theresa M., and Nancy K. Baym. 2015. What does the selfie say? International Journal of Communication 9: 1588-606.

Shensa, Ariel, Jaime E. Sidani, Liu Yi Lin, Nicholas David Bowman, and Brian A. Primack. 2016. Social media use and perceived emotional support among US young adults. Journal of Community Health 41: 541-49. [CrossRef] [PubMed]

Aaron, Smith, and Dana Page. 2015. Smartphone Use in 2015. Available online: http:/ /www.pewinternet.org/ files/2015/03/PI_Smartphones_0401151.pdf (accessed on 12 July 2018).

Stald, G. 2008. Mobile Identity: Youth, identity, and mobile communication media. In Youth, Identity, and Digital Media. Edited by D. Buckingham. The John D. and Catherine T. MacArthur Foundation Series on Digital Media and Learning; Cambridge: The MIT Press, pp. 143-64. [CrossRef]

Tajfel, Henri, ed. 1978. Differentiation between Social Groups. London: Academic Press.

Tajfel, Henri, and John C. Turner. 1986. The social identity of intergroup behavior. In Psychology of Intergroup Relations. Edited by Stephen Worchel and William G. Austin. Chicago: Nelson, pp. 7-24.

Tanis, Martin, and Torm Postmes. 2005. A social identity approach to trust: Interpersonal perception, group membership and trusting behavior. European Journal of Social Psychology 35: 413-24. [CrossRef]

Tekman, Hasan Gurkan, and Nuran Hortaçsu. 2002. Music and social identity: Stylistic identification as a response to musical style. International Journal of Psychology 37: 277-85. [CrossRef] 
Thurlow, Crispin. 2005. Deconstructing adolescent communication. In Talking Adolescence: Perspectives on Communication in the Teenage Years. Edited by Angie Williams and Crispin Thurlow. New York: Peter Lang, pp. 1-20.

Tropp, Linda R., and Stephen C. Wright. 2001. Ingroup identification as the inclusion of ingroup in the self. Personality and Social Psychology Bulletin 27: 585-600. [CrossRef]

Turner, John C. 1982. Towards a cognitive redefinition of the social group. In Social Identity and Intergroup Relations. Edited by Henri Tajfel. Cambridge: Cambridge University Press, pp. 15-40.

Valkenburg, Patti M., and Jochen Peter. 2007a. Internet communication and its relationship to wellbeing: Identifying some underlying mechanisms. Media Psychology 9: 43-58. [CrossRef]

Valkenburg, Patti M., and Jochen Peter. 2007b. Preadolescents' and adolescents' online communication and their closeness to friends. Developmental Psychology 43: 267-77. [CrossRef] [PubMed]

Valkenburg, Patti M., Alexander P. Schouten, and Jochen Peter. 2005. Adolescents' identity experiments on the Internet. New Media E Society 7: 383-402.

Walsh, Shari Poldi, Katherine Marie White, and Ross McDonald-Young. 2009. The phone connection: Qualitative exploration of how belongingness and social identification relate to mobile phone use amongst Australian youth. Journal of Community \& Applied Social Psychology 19: 225-40.

World Health Organization (WHO). 2018. Adolescent Development. Available online: http://www.who.int/ maternal_child_adolescent/topics/adolescence/development/en/ (accessed on 12 July 2018).

Williams, Angie, and Crispin Thurlow, eds. 2005. Talking Adolescence: Perspectives on Communication in the Teenage Years. New York: Peter Lang.

(C) 2018 by the author. Licensee MDPI, Basel, Switzerland. This article is an open access article distributed under the terms and conditions of the Creative Commons Attribution (CC BY) license (http:// creativecommons.org/licenses/by/4.0/). 